Aleksandra Rabrenović, PhD*

Review scientific paper

UDC: 351.74(497.1)

doi: 10.5937/spz0-20224

\title{
CHALLENGES IN RECRUITMENT AND SELECTION OF THE POLICE OFFICERS IN MONTENEGRO
}

\author{
Abstract
}

The objective of the paper is to analyse the legal framework and challenges in the recruitment and selection of the police officers in Montenegro. In the first section of the paper the author examines the international standards regarding recruitment and selection of the public sector employees, including the police officers, which serve as a benchmark for assessing the respective Montenegrin legal framework and its implementation. In the second part of the paper, the author analyses the relevant provisions of the Law on Internal Affairs and the Civil Service Law which refer to the recruitment and selection of the police officers. The author concludes that the current legal framework is not fully aligned with the international standards, especially since it prescribes the exceptions to carrying out of the public competition. Current challenges in the recruitment and selection process result in the low level of confidence of the public in its fairness. For these reasons, it is necessary to undertake measures to increase the merit in the recruitment and selection of the police officers and reduce secrecy and patronage.

Keywords: police officers, recruitment and selection, public service, Montenegro.

\section{Introduction}

Efficient human resource management in the police one of the preconditions for effective performance of the police duties in modern democracies. ${ }^{1}$ Police officers carry out complex tasks related to maintaining public order, protecting and upholding fundamental human

\footnotetext{
* Research Fellow, Institute of Comparative Law, Belgrade, e-mail: a.rabrenovic@iup.rs.

${ }^{1}$ Z. Vukašinović Radojičić, "Specifičnosti sistema službeničkih odnosa u policiji”, Pravni život 10/2013, 335-347.
} 
rights and freedoms, preventing and combating crime, as well as providing assistance and services to citizens. The police officers' performance and effectiveness in carrying out law enforcement and public order duties depend to a large extent upon the level of their professional knowledge, skills and attitudes. For these reasons, the area of human resources management in the police has been a subject of significant changes in a number of countries over the past decades, aiming to improve all human resources management aspects, including attraction and recruitment, professional development and training of police personnel. ${ }^{2}$

Montenegro is currently in the process of the EU accession, which, inter alia, requires strengthening of administrative capacities of the police. ${ }^{3}$ Montenegro needs to adopt and implement instruments from the Chapter 24 - Justice, Freedom and Security, which relate to the development and strengthening the capacities of the police. One of the requirements of the Chapter 24 is to create a reliable and professional police system that will be able to adapt to the EU and Schengen needs. Development of an effective human resource management system is one of the preconditions for achieving that goal.

This paper analyses one of the segments of the human resources management in the police of Montenegro - the process of recruitment and selection of the police officers. The first section of the paper examines the international standards regarding recruitment and selection of the public sector employees, including the police officers, which serve as a benchmark for assessing the respective Montenegrin legal framework and its implementation. In the second part of the paper, the relevant provisions of the Law on Internal Affairs and the Civil Service Law, which refer to the recruitment and selection of the police officers, are examined. The concluding section of the paper provides guidance on how to improve the current legal framework, as a basis for increasing the transparency and strengthening the merit and integrity of the recruitment and selection process of the police officers.

\footnotetext{
2 J. Drew, T. Prenzler, "The Evolution of Human Resources Management in Policing", in: The Fizdgerald Legacy: Reforming Public Life in Australia and Beyond (eds. C. Lewis, J. Ransley, R. Homel,), Australian Academic press, 2010, 134-153.

${ }^{3}$ The Police Directorate Strategy Development 2016-2020, Podgorica, December 2015.
} 


\section{International human resource management standards in the public service regarding recruitment and selection}

The area of human resources management in the police is not, as such, subject to specific international standards. The way Governments around the world manage their human resources is considered to be an area of a national interest. The same holds true for the human resources management in the police, which is traditionally an organisation whose operation is shielded with a veil of secrecy. Nevertheless, there are several general international instruments which define the best international standards in the area of HRM in the public service, including the police organisations.

The key internationally accepted human resource management standard in the public administration is the principle of merit. The merit principle can broadly be defined as the setting up of a special public administration value system, based on professionalism, competence and integrity to pursue the public interest. ${ }^{4}$ The merit-based system represents a counterbalance to that of political loyalty, popularly known as the "patronage or the spoils system", in which public administration posts are filled solely on the basis of political connections instead of professional merit. ${ }^{5}$

Several international instruments require the observance of the merit principle in the recruitment and selection of public servants, including the police officers. For example, the UN Convention against Corruption (2003) especially emphasizes the importance of merit and transparency in the recruitment process of public servants. In the similar vein, the Council of Europe's Recommendation No. R (2000) 6 on the Status of Public Officials in Europe, ${ }^{6}$ stresses the need for the existence of legal framework concerning the status of public officials and recruitment and selection based on merit and fair and open competition. The Council

\footnotetext{
${ }^{4}$ P. W. Ingraham, "Building Bridges over Troubled Waters: Merit as a Guide", Public Administration Review, 2006, 486-495.

${ }^{5}$ In the XIX century in the USA, the "spoils system" was thought to be the best state administration system for a democratic society. The US President Jackson said: "in a country where services were created solely for the benefit of people, no individual is entitled to serve more than others." However, the spoils system gave rise to rampant corruption and abuse in the US federal administration system, and was therefore abandoned when the Pendleton Act was passed in 1883 due to a civil service reform movement. Cf. E. Pusić, Nauka o upravi, Školska knjiga, Zagreb 1973, 178-179.

${ }^{6}$ The Council of Europe's Recommendation No. R (2000) 6 of the Committee of Ministers to member states on the status of public officials in Europe, adopted by the Committee of Ministers on 24 February 2000 at the $699^{\text {th }}$ meeting of the Ministers' Deputies. The recommendation constitutes a follow up on the Parliamentary Assembly Recommendation 1303 (1996) which asked the Committee of Ministers to include the drawing-up of European legal instruments on the civil service and the Parliamentary Assembly Recommendation 1322 (1997) on civil service in an enlarged Europe.
} 
of Europe's Code of Police Ethics, inter alia, stresses the need that recruitment process of the police officers is based on the merit principle and that the selection of candidates should be based on objective criteria and testing procedure. The police personnel should be recruited on the basis of their personal qualifications and experience which is relevant to police operation and assignments. ${ }^{8}$ The Code also emphasises the need that the recruitment policy should aim at attracting candidates from various parts of the society: both men and women from different social groups, including ethnic minority groups, with the overall objective of making police personnel reflect the society they serve. ${ }^{9}$

Recruitment and selection in the police is not explicitly part of the EU acquis communautaire, but is governed by soft acquis, comprising shared standards of the EU member states and affecting indirectly the development of the national law. ${ }^{10}$ Though not legally binding, these standards have significant practical effects on the aspiring countries, given that the European Commission assesses their progress against such standards. To provide a more detailed elaboration of the EU Commission's human resource management requirements, in 2014 SIGMA/OECD" programme prepared a document entitled "Principles of Public Administration" in 2014. ${ }^{12}$ One of the areas covered within the principles is the field of human resources management, which are relevant for public servants, including the police officers. ${ }^{13}$

\footnotetext{
${ }^{7}$ European Code of Police Ethics, Recommendation No. (2001)10 adopted by the Committee of Ministers of the Council of Europe on 19 September 2001.

${ }^{8}$ Ibid.

${ }^{9}$ Ibid.

${ }^{10}$ M. Keune, ,EU Enlargement and Social Standards - Exporting the European Social Model?”, The European Union and the Social Dimension of Globalisation, How the EU Influences the World (eds. J. Orbie, L. Tortell), Routledge, $2009,52$.

${ }^{11}$ Having recognized the importance of well-regulated and organized state administration for compliance with membership requirements in all sector areas, in 1992 EU and OECD founded SIGMA - Support for Improvement in Governance and Management. This programme aims at supporting public administration reform activities of (potential) EU candidate countries. SIGMA, largely financed through EU PHARE, represents one of the main European Commission's instruments for promoting the development of public administration capacity in Central and Eastern Europe, and providing technical assistance to candidate countries.

${ }^{12}$ SIGMA/OECD, Principles of Public Administration, OECD publishing, 2014.

${ }^{13}$ SIGMA defines a concept of a public servant based on the European Court of Justice (ECJ) case 149/79 and European administrative law principles defined in SIGMA paper No. 27, 1999 and includes in this concept the following organisations: 1) ministries and administrative bodies reporting directly to the Government, Prime Minister or ministers, i.e. civil service strictly speaking, which includes the police organisations; 2) administrations of the Parliament, the President and the Prime Minister; 3) other administrative bodies at the level of central administration if they exercise public authority conferred by public law and are responsible for safeguarding the general interest of the state or other public bodies 4) independent constitutional bodies reporting directly to Parliament. Cf. SIGMA/OECD, Principles of Public Administration, OECD publishing, 2014, 42-43.
} 
SIGMA requires that the recruitment and selection process, either external or internal and regardless of the category/class of public servant, is clearly based on merit, equal opportunity and open competition. It also requires that the law which governs the position of public servants be clearly establishes that any form of recruitment and selection not based on merit is considered legally invalid. ${ }^{14}$

In order to ensure impartiality, competition procedure needs to be implemented by recruitment and selection committees, operating independently from political influence. Members of these committees should possess solid understanding of the tasks performed in the advertised position, along with the skills and knowledge required for their performance. ${ }^{15}$ They also need to be trained on selection procedures in order to be able to implement them in a consistent and fair fashion.

Special attention is paid to senior, i.e. managerial civil servants. SIGMA requires that direct or indirect political influence on senior managerial positions be prevented. This should be achieved by including the senior managerial positions into the scope of public service and establishment of the clear criteria for recruiting persons to the senior managerial positions. The recruitment and selection process to the senior managerial positions, either external or internal, should be based on merit, equal opportunities and open competition, Finally, the termination of employment of public servants holding senior managerial positions should only admissible in cases explicitly provided for, and under the procedural provision established in the law. ${ }^{16}$

\section{Strategic and legal framework for recruitment and selection of the police officers in Montenegro}

The recruitment and selection process in the police should be viewed within the broader strategic framework providing strategic guidelines for the development of the Montenegrin police. In that regard, particularly important are the following documents: the Public Administration Reform Strategy 2016-2020; ${ }^{17}$ the Montenegrin Fiscal Strategy 2017-2020; ${ }^{18}$ and the Human Resources Management Strategy of the Police Directorate for the period of 2019-2024 and Action plan for its implementation for

${ }^{14}$ Ibid., 48.

${ }^{15}$ Ibid.

${ }^{16}$ Ibid., 50.

${ }^{17}$ Government of Montenegro, Public Administration Reform Strategy 2016-2020.

${ }^{18}$ Government of Montenegro, Fiscal Strategy of Montenegro 2017-2020. 
2019-2020. ${ }^{19}$

The Public Administration Reform Strategy 2016-2020, apart from other priorities, sets out those relating to the management of human resources in the public administration system. The Strategy places particular importance on the need to improve the recruitment and professional development system. The Montenegro Fiscal Strategy for 2017- 2020, addresses the need to ensure more efficient public administration as an important factor leading to better business environment necessary for further investment and overall economic growth. The key challenge in this area is to make budget savings and optimize the number of public authorities and their employees, including the Police Administration.

In July 2018, the Government of Montenegro adopted the Public Administration Optimisation Plan 2018-2020, ${ }^{20}$ which will also affect recruitment and selection in the police. This plan defines, inter alia, the following measures: restriction of recruitments under open-ended employment contracts in state authorities until 1 March 2019; ending fixed-term employments upon expiration of such term, without the possibility of extension, until 1 March 2019.

The most important document which provides a strategic guidance for all aspects of human resources management in the police, including the recruitment and selection process, is the Human Resources Management Strategy in the Police Directorate 2019-2024 with the Action Plan for its implementation for the period of 2019-2020. These documents were adopted by the Government only recently, in September 2018. One of the key objectives of the Strategy is to attract and recruit high quality candidates for the police job, as will be discussed in more detail in the course of the ensuing analysis.

The legal framework regarding recruitment and selection of police officers in Montenegro is currently regulated by two key pieces of legislation: the Law on Internal Affairs ${ }^{21}$ and the Law on Civil Servants and Employees (hereinafter Civil Service Law). ${ }^{22}$

It should also be noted that over the past year, the Ministry of the Interior/the Police Directorate of Montenegro have been working on a new draft Law on Internal Affairs, which aims to improve the current legal framework governing human resource management in the police,

\footnotetext{
${ }^{19}$ Government of Montenegro, Human Resources Management Strategy in the Police Directorate 20192024 and the Action Plan for its implementation for the period 2019-2020.

${ }^{20}$ Government of Montenegro, Public Administration Optimisation Plan, 2018-2020.

${ }^{21}$ Law on Internal Affairs, Official Gazette of Montenegro, No. 44/12,36/13,1/15, 87/2018.

${ }^{22}$ Law on Civil Servants and Employees (hereinafter CSL), Official Gazette of Montenegro, No. 2/18.
} 
including the recruitment and selection issues. As the current legal text is only in the form of a draft, which is not publicly available, it, however, will not be analysed within this paper.

\section{Assessment of the legal framework and the implementation challenges}

The criteria for entering into employment into the police service, prescribed by the Law on Internal Affairs, are generally in line with the international standards. In addition to the general recruitment criteria regulated by the Civil Service Law, ${ }^{23}$ the Article 85 of the Law of Internal Affairs requires a person to meet the following criteria in order to be recruited in the police service: 1) to have secondary school education (general or expert) as a minimum education requirement 2) to have special physical abilities 3 ) to be worthy to carry out police duties. ${ }^{24}$ The Law specifies the term of "unworthiness to carry out the police duties" in the following manner: if a person has been convicted to a criminal offense of endangering public traffic on roads made under the influence of alcohol, drugs or other psychoactive substances; a person punished for an offense against public order and peace with elements of violence or another offense that makes him/her unworthy of carrying out internal affairs tasks; a person whose previous behaviour, habits or preferences indicate unreliability for doing these jobs. ${ }^{25}$

The legal definition of the "unworthiness" of a candidate for a police officer, however, provides grounds for concern and discretion. The Law on Internal Affairs prescribes that the unworthiness of a police officer's candidate is tested in accordance with a special act adopted by a minister, ${ }^{26}$ i.e. the Rulebook on Establishing the Worthiness of Persons to Perform the Police Duties. ${ }^{27}$ The provisions of this Rulebook are not, however, very comprehensive and do not provide clear criteria on how the "unworthiness" is to be measured. This poses a risk for discretion in the recruitment and selection process.

The Law on Internal Affairs also requires that during the recruitment and selection process special care be taken to ensure proportional

\footnotetext{
${ }^{23}$ Articles 36 of the CSL.

${ }^{24}$ Article 85, paragraph 1 of the Law on Internal Affairs.

${ }^{25}$ Article 85, paragraph 2 of the Law on Internal Affairs.

${ }^{26}$ Article 85, paragraph 3 of the Law on Internal Affairs.

${ }^{27}$ Rulebook on Establishing Worthiness of Persons to Perform the Police Duties, Official Gazette of Montenegro No. 44/23.
} 
representation of the members of minority peoples and other minority national communities. ${ }^{28}$ This provision is in line with the international standards, especially the earlier mentioned Code of the Police Ethics of the Council of Europe.

The key contentious issue regarding recruitment and selection is a possibility to recruit a person to a position of a police officer without a public competition, which clearly goes against the principle of merit. Namely, the paragraph 1 of the Article 86 of the Law on Internal Affairs stipulates that a public competition is a mandatory method of selection of police officers. Paragraph 2 of the same article, however, envisages exceptions to this rule. Public competition is not required for vacancies which are identified in the MoI/PA internal organisation and systematisation rulebook. ${ }^{29}$

In spite of the fact that the number of positions exempted from the public competition is relatively small (3-5\% of the total number of posts in $\mathrm{MoI} / \mathrm{PA}$ ), these exceptions are not in line with the international standards. The current exceptions to the public competition allow the existing practice that the police officers from the Ministry of Interior or the Police Directorate can simply "approach" a candidate they consider suitable for a certain positions, without any prior selection or testing process. This opens wide possibilities for discretionary decisions and recruitment based on party or political connections instead of the merit principle. These exceptions are also contrary to the recruitment standards required by the SIGMA Principles of Public Administration or the CoE Code of Police Ethics.

It may, however, be argued that due to specificities of the police organisations and the nature of the police work, recruitment and selection for certain vacancies in the police (especially in the criminal department) do require competition procedures which are specifically tailored to the police needs. In the current legal set up, all vacancies which are advertised need to be filled in cooperation with the Human Resources Management Authority. For a certain types of positions, such as an undercover agent, or other criminal investigation officers, it may be more suitable that the competition procedure is carried out within the police organisation itself. These procedures, however, also need to be based on the principle of merit and transparency.

Let us now have a closer look at the open competition procedure for recruitment of police officers in case when exceptions do not apply.

\footnotetext{
${ }^{28}$ Article 86, paragraph 5 of the Law on Internal Affairs.

${ }^{29}$ Article 86, paragraph 4 of the Law on Internal Affairs.
} 
This procedure is carried out in cooperation with the Human Resources Management Authority and is regulated in more detail by the provisions of the Civil Service Law $^{30}$, since it is applicable to all other civil service institutions in Montenegro.

Each recruitment and selection procedure is carried out by an ad hoc competition commission, which is composed of three members. One of the members of the competition committee is a representative of the Ministry of Interior/Police Directorate, who should, as a rule, be the head of an organisational unit in which the vacancy is filled; the second one is a representative of the HRMA; and the third member is an expert in the field. ${ }^{31}$ Although the composition of the competition commissions in generally in line with the SIGMA standards, in practice it is often the case that managers of organisational units (especially in the decentralised police units - security centres), often do not take part in these panels and usually meet their new recruit only after the recruitment process is finalised.

The selection process is regulated in more detail by a Decree ${ }^{32}$ and is carried out on the basis of the written test and the interview. ${ }^{33}$ The written tests comprises the theoretical and the practical part. Only the candidates who obtain high scores on the theoretical and practical part of the written test are eligible to pass to the final stage of the selection process based on the structured interview. The rules for the selection process are fully in line with the international standards, but it is still difficult to assess their effectiveness in practice as they have only recently started to be implemented, in July 2018.

At the end of the selection process, the Human Resources Management Authority provides a police director with three shortlisted candidates (or more, if they have the same score) so that he/she can choose one from the list. ${ }^{34}$ Although director, as a rule, must choose the highestranking candidate, he/she can also choose some other candidate from the list of successful candidates. Discretionary power of the police director to select any of the shortlisted candidates opens the door to patronage and politicisation..$^{35}$ In practice, decisions to recruit candidates other than those

\footnotetext{
${ }^{30}$ Articles $34-51$ of the CSL.

${ }^{31}$ Article 46, paragraph 3 of the CSL.

32 Decree on the Criteria and Methods on Carrying out Testing of Knowledge, Abilities, Competences and Skills for Work in State Authorities, Official Gazette of Montenegro, No. 50/2018 adopted on 20 July 2018.

${ }^{33}$ Article 5-15 of the Decree on the Criteria and Methods on Carrying out Testing of Knowledge, Abilities, Competences and Skills for Work in State Authorities.

${ }^{34}$ Article 47, paragraph 3 of the CSL.

${ }^{35}$ M. Milošević, "Upravljanje ljudskim resursima", in: Procjena integriteta policije u Crnoj Gori (ed. S. Muk), Institute Alternative, Podgorica 2016, 35.
} 
with the highest score largely remain unexplained, resulting in problems during appeal and court procedures. These problems are expected to be resolved, at least to some extent in the future, as the new Civil Service Law requires mandatory conducting of the interview with all shortlisted candidates and mandatory justification for the appointment decision. ${ }^{36}$

Finally, one of the most important ways to enter into employment in the police of Montenegro is to complete the Police Academy course of education. The Police Academy education is considered to be postsecondary vocational in the duration of two years. According to the Decision on the Establishment of the Public Institution - Vocational School "Police Academy", ${ }^{37}$ the Academy is founded as a post-secondary vocational school delivering vocational education programmes for which the Police Academy is licensed.

The Police Academy graduates, however, do not automatically enter into employment in the Police Administration after graduation. They, instead, have to either apply for a vacancy announcements of the Ministry of Interior/the Police Academy or can be admitted without a competition procedure. The latter possibility is possible if the vacancy for which they apply is marked in the Rulebook on Internal Organisation and Systematisation as "confidential". This again opens up a wide leeway of discretion in the recruitment process.

The existing problems related to police officer recruitment are also reflected in a low level of public confidence in impartiality of the recruitment process. An opinion poll from September $2017^{38}$ shows that many Montenegrin citizens believe the police selection and recruitment process takes place in the presence of bribery, through political and family and friends connections (Graph 1), regardless of the public competition being formally organised.

\footnotetext{
${ }^{36}$ Article 48, paragraph 4 of the CSL.

${ }^{37}$ Decision on Organisation of the Public Institution of Higher Vocational Education "The Police Academy", Official Gazette of Montenegro, No. 40/2012.

${ }^{38}$ Pointpulse, 'Report - The citizens' opinion of the police, Results of the public opinion survey for Montenegro," September, 2017.
} 


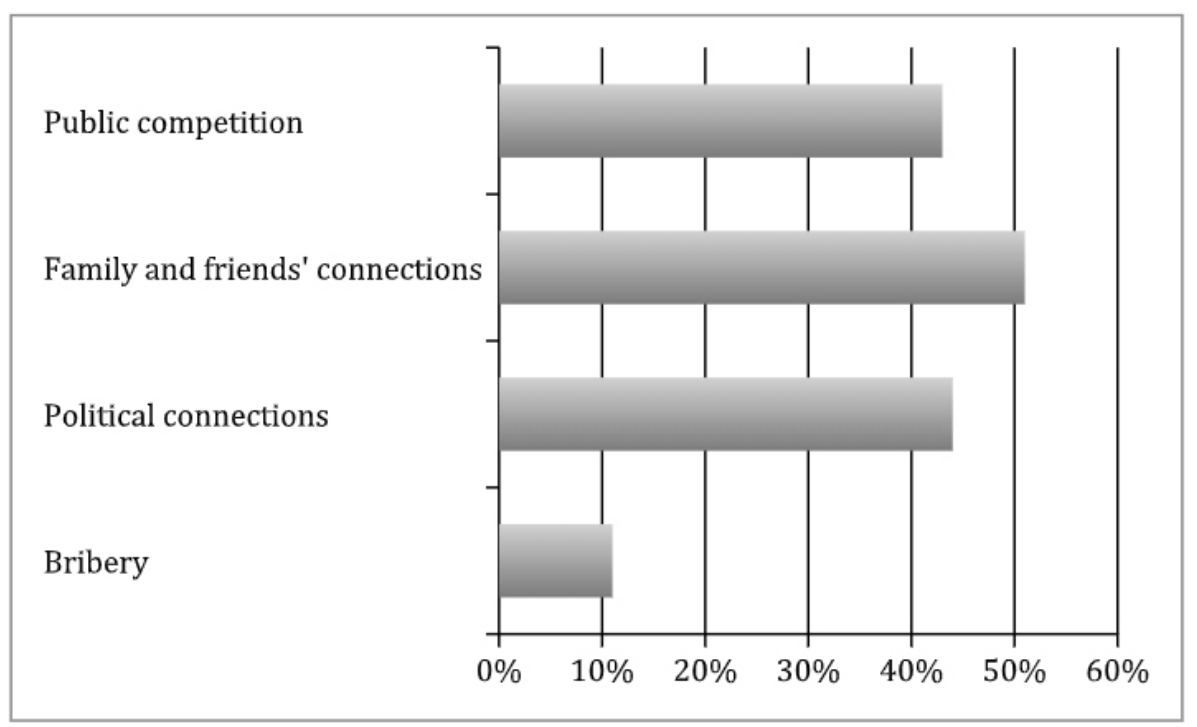

Figure 1. Citizen perception of how the Police Administration of Montenegro recruits its personnel ${ }^{39}$

In the view of the existing general challenges related to human resource management activities in the police, the Government of Montenegro has recently adopted the Human Resources Management Strategy in the Police Directorate, which outlines recommendations for overcoming the current challenges in all HRM aspects, including the recruitment and selection of the police officers. The proposed strategic measures with respect to recruitment and selection include: 1) conducting a media campaign to attract desirable police job candidates, with emphasis on attracting women; 2) introducing an obligation of the Police Directorate to recruit persons who have graduated from the police education institution; 3) regulating, by a separate piece of legislation adopted by the minister, the filling of vacancies which are currently not advertised (to be advertised in accordance with a special procedure); 4) regulating in more detail the security vetting activities taken while selecting candidates.

The attainment of the objective is to be measured by two indicators which are defined in the following manner: 1) the number of police education graduates whose education was funded by the budget who are recruited by the Police Directorate (in percentages) - baseline value for ${ }^{39}$ Ibid. 
2017 is $70 \%$, while the target value for 2024 is $100 \%$; and 2) percentage of the Police Directorate vacancies which are filled in compliance with the prescribed recruitment procedures; the baseline value for 2017 is 90 per cent, while the target value for 2024 is 100 per cent.

\section{Recruitment and selection of senior officials in the Police}

Senior police managers, including director and deputy director of the Police Administration, enjoy a special legal status. Under the Civil Service Law, the position of police director belongs to the "head of authority" category, while deputy directors fall under the "senior managerial staff" category. ${ }^{40}$ Appointment and dismissal of both director and his/her deputy are regulated by the Civil Service Law. ${ }^{41}$

Requirements for the jobs of police director and deputy director are defined by the law, which is in line with the international standards. The minimum requirement for these positions, defined by the Law on Internal Affairs, are as follows: 1) for the police director - university education and 15 years of work experience, 5 of which in managerial positions in the police, court, prosecutor's office or the National Security Agency. ${ }^{42}$ In the case of a deputy director, the minimum requirements include higher education and 10 years of work experience, 3 of which in managerial positions in the police, court, prosecutor's office or the National Security Agency. ${ }^{43}$ It may, however, be argued that these work experience requirements are quite broadly defined, as they do not include the previous work experience in the police. Opening up a possibility for so called "outsiders" from the police system to become managers of the police organisation may bring about a number of challenges and difficulties in practice, due to a lack of knowledge of the specificities of the work of the police organisation.

Applicants for the positions of a director and an assistant director are tested by a competition commission, formed by the Human Resource Management Authority, while the formal appointment decision is issued by the Government. The Government appoints the director and his/her assistants for a five-year term of office. Having tested the candidates for deputy director's position, the HRMA supplies police director with the list of successful candidates. Once a director conducts interviews with

\footnotetext{
${ }^{40}$ Article 18 of the Civil Service Law.

${ }^{41}$ Articles 56-59 of the Civil Service Law.

${ }^{42}$ Article 9, paragraph 1 of the Law on Internal Affairs.

${ }^{43}$ Article 9, paragraph 6 of the Law on Internal Affairs.
} 
all of them, he/she is required to propose one of them to the Government to make a formal appointment. In the case of selection of the Police Administration director, the HRMA is to provide such list to the minister of interior, who proposes the appointment of a prospective candidate to the Government. ${ }^{44}$ In the case of recruitment of the police director, the Government is also obliged to nominate the proposal for the appointment to the Parliament of Montenegro for the purpose of providing an opinion on the perspective candidate(s). ${ }^{45}$ The Assembly, after hearing in the competent working body, provides an opinion on the proposed candidate. ${ }^{46}$

In practice, changes of the top police management personnel are quire frequent, which impedes the continuity of operation and adversely affects the performance of the police. Such frequent changes in the top management structure trigger replacement of the middle management (the so-called expert-management staff), who cannot be assigned to other appropriate posts, thus becoming "unassigned personnel". The category of "unassigned personnel" includes the police officers who have been dismissed from their posts and have not been assigned to new duties, which means that they actually do not work, but continue to enjoy the employment benefits, such as regular pay, health and pension insurance. The mere existence of such a category of staff is a clear exemplary of the deficiencies and challenges of the current human resource management system which the Montenegrin police is currently facing and which yet need to be overcome.

\section{Conclusion}

The recruitment and selection of process of the police officers of Montenegro is faced with important challenges. Even though the basic prerequisites for applying the merit principle have been generally established through the existing legislative framework, the police still has to increase transparency and ensure merit in the recruitment and selection process. The police organisation, just like other public sector segments, is increasingly pressured to recruit officers enjoying appropriate political or other kind of support. This is partly the consequence of the economic crisis, which reduced employment opportunities in the private sector and left little choice to job seekers. The legislation in place, which makes it possible to get a job without

\footnotetext{
${ }^{44}$ Article 9, paragraph 2 of the Law on Internal Affairs.

${ }^{45}$ Article 9, paragraph 3 of the Law on Internal Affairs.

${ }^{46}$ Article 9, paragraph 4 of the Law on Internal Affairs.
} 
a public competition process, provides a fertile ground to such practice.

The recently adopted HRM Strategy for the Police Administration has introduced several important strategic measures for improving the current situation in the recruitment and selection process in the police. One of the most important measures envisaged by the Strategy is the requirement that all vacancies should be filled on the basis of the competition, which is certainly the step in the right direction. Other strategic measures, such as for example, regulating the security vetting activities taken while selecting candidates in more detail are also expected to bring about improvements in this important area.

One of the key areas which, however, have been neglected by the Strategy is the need to reduce politicisation and increase fairness in the recruitment and selection of the senior police officials. In order to overcome this challenge it is advisable to introduce a more detailed appointment/ nomination procedure for police director and deputy director, including stricter requirements in terms of years of experience that candidates for these positions must have. It would also be important to require from such candidates longer relevant police experience (for example the minimum of 15 years of police service), in order to be able to effectively respond to the day-to-day challenges of managing the police organisation.

Finally, if we want to substantively improve the recruitment and selection process in the police of Montenegro, changes of the strategic and legal framework will not be sufficient. The experience of the other transitional countries shows that internalisation of the merit principle in the public service is a slow and reversible process, which very much depends on the broader and political and social environment. ${ }^{47}$ In order to achieve substantive improvements in this area, there is a need to build awareness of all key societal stakeholders, primarily politicians, that professional administration is the main factor to ensure implementation of the Government programs and assist them to win citizens' trust in the next elections. This process, however, depends on the pace of the democratization of the country, which requires time and patience.

\footnotetext{
${ }^{47}$ J.M. Sahling, "Sustainability of Civil Service Reforms in Central and Eastern Europe Five Years after EU Accession”, SIGMA paper 44, 2009, GOV/SIGMA (2009)1, OECD/SIGMA publishing.
} 


\section{References}

Pusić, E., Nauka o upravi [Administrative Science], Školska knjiga, Zagreb 1973. Vukašinović Radojičić Z., Pravna pitanja službeničkih odnosa [Legal Civil Service Issues], edition monographs, book 5, Criminalistic-Police Academy, Belgrade, 2015.

Drew, J., Prenzler, T., "The Evolution of Human Resources Management in Policing", in: The Fizdgerald Legacy: Reforming Public Life in Australia and Beyond (eds. C. Lewis, J. Ransley, R. Homel), Australian Academic press, 2010, 134-153.

Ingraham, P. W., "Building Bridges over Troubled Waters: Merit as a Guide“, Public Administration Review, 2006, 486-495.

Keune, M., „EU Enlargement and Social Standards - Exporting the European Social Model?”, The European Union and the Social Dimension of Globalisation, How the EU Influences the World (eds. J. Orbie, L. Tortell), Routledge, 2009, 52.

Milošević, M., "Upravljanje ljudskim resursima" ["Human Resources Management"], in: Procjena integriteta policije u Crnoj Gori [Integrity Assessment of the Police in Montenegro] (ed. S. Muk), Institute Alternative, Podgorica 2016, 35.

Vukašinović Radojičić, Z., "Specifičnosti sistema službeničkih odnosa u policiji" ["Specificities of the Civil Service Relations in the Police"], Pravni život 10/2013, 335-347.

\section{Legislative sources}

Law on Internal Affairs, Official Gazette of Montenegro No. 44/12,36/13,1/15, 87/18). Law on Civil Servants and State Employees, Official Gazette of Montenegro No. $2 / 2018$.

Law on Higher Education, Official Gazette of Montenegro No. 44/14, 52/14, $47 / 15,40 / 16,42 / 17$.

Decision on the establishment of the post-secondary vocational school "Police Academy" Official Gazette of Montenegro No. 40/2012.

Rulebook on establishing worthiness of persons to perform police duties, Official Gazette of Montenegro No. 44/23.

Decree on the Criteria and Methods on Carrying out Testing of Knowledge, Abilities, Competences and Skills for Work in State Authorities, Official $\mathrm{Ga}$ zette of Montenegro, No. 50/2018 adopted on 20 July 2018. 
European Code of Police Ethics (Recommendation (2001)10 adopted by the CoE Council of Ministers on 19 September 2001.

The Council of Europe's Recommendation No. R (2000) 6 of the Committee of Ministers to member states on the status of public officials in Europe, adopted by the Committee of Ministers on 24 February 2000 at the $699^{\text {th }}$ meeting of the Ministers' Deputies.

SIGMA/OECD, Principles of Public Administration, 2014, OECD publishing.

\section{Strategic and other documents}

MoI of Montenegro, Police Administration Development Strategy 2016-2020, Action Plan for the Implementation of the Police Administration Development Strategy 2016-2017.

Government of Montenegro, Fiscal Strategy of Montenegro 2017-2020.

Government of Montenegro, Public Administration Reform Strategy 2018-2022.

Government of Montenegro, Public Administration Optimisation Plan 2019-2020. Pointpulse, "Report - The citizens' opinion of the police, Results of the public opinion survey for Montenegro," September, 2017.

\section{Dr Aleksandra Rabrenović}

Naučni saradnik, Institut za uporedno pravo, Beograd

\section{IZAZOVI U POSTUPKU ZAPOŠLJAVANJA POLICIJSKIH SLUŽBENIKA U CRNOJ GORI}

Rezime

Cilj rada je analiza pravnog okvira i prakse zapošljavanja policijskih službenika u Crnoj Gori. U prvom delu rada autor analizira međunarodne standarde koji se odnose na zapošljavanje javnih službenika, uključujući i policijske službenike, koji služe kao osnov za procenu pravnog okvira zapošljavanja policijskih službenika i njegove primene u Crnoj Gori. U drugom delu rada, autor analizira relevantne odredbe Zakona o unutrašnjim poslovima i Zakona o državnim službenicima i nameštenicima koji se odnose na zapošljavanje i selekciju policijskih službenika. Autor zaključuje da trenutni pravni okvir nije u potpunosti 
usklađen sa međunarodnim standardima, posebno zbog toga što predviđa izuzetke od sprovođenja javnog konkursa. Trenutni izazovi u procesu zapošljavanja policijskih službenika kao posledicu imaju i nizak stepen poverenja javnosti u pravičnost ovog procesa. Iz svih pomenutih razloga, neophodno je preduzeti mere na unapređenju pravnog okvira koji reguliše zapošljavanje, kao osnove za primenu principa profesionalnih sposobnosti pri zapošljavanju policijskih službenika.

Ključne reči: policijski službenici, zapošljavanje, javna služba, Crna Gora. 